\title{
Ileus due to Meckel's diverticulum: case reports
}

\author{
Meckel divertikülüne bağlı ileus: Olgu sunumları
}

\section{Selim SÖZEN, Ömer TOPUZ, Mustafa TÜKENMEZ, Ömer Fazıl BİLGİN, Yunus DÖNDER}

\begin{abstract}
Meckel's diverticulum is the most common congenital anomaly of the small intestine, with an estimated incidence of approximately $1-3 \%$ in the general population. Intestinal obstruction is the most common complication in adult patients. Since accurate diagnosis before the operation is difficult, decision for surgery is delayed, and serious problems may be encountered. Here in, we present the diagnosis and management of our patients with intestinal obstruction due to Meckel's diverticulum.
\end{abstract}

Key Words: Ileus; intestinal obstruction; Meckel's diverticulum.
Meckel divertikülü ince bağırsağın en sık rastlanan dogumsal anomalisi olup genel nüfusta \%1-3 oranında görülür. Erişkinlerde en sık görülen komplikasyonu bağırsak tıkanıklığıdır. Ameliyat öncesi tanının sıklıkla mümkün olmaması ve ameliyatta gecikilmesi ciddi sorunlara neden olabilir. Bu yazıda, Meckel divertikülü nedeniyle bağırsak tıkanıklığı olan hastaların tanısı ve tedavi yönetimi sunuldu.

Anahtar Sözcükler: İleus; bağırsak tıkanıklı̆̆ı; Meckel divertikülü.
Meckel's diverticulum is the most common congenital anomaly of the gastrointestinal tract, occurring in $2-3 \%$ of the general population. ${ }^{[1,2]}$ In the majority of patients, Meckel's diverticulum is asymptomatic. ${ }^{[3,4]}$ Only $16 \%$ of Meckel's diverticula give rise to symptoms ${ }^{[5]}$ The most common presentation in adults is intestinal obstruction. The most common means of obstruction is intussusception with the Meckel's diverticulum being the lead point. Other causes of obstruction include volvulus around fibrous bands adherent to the umbilicus, Littre's hernia and diverticular strictures, and loop formations of Meckel's diverticulum. ${ }^{[6,7]}$

This report summarizes three cases and presents a brief review of the literature.

\section{CASES REPORTS}

Case 1-A 65-year-old male patient presented with abdominal pain, anorexia, nausea, vomiting, and abdominal bloating. On his physical examination, there were abdominal tenderness, rebound and increased bowel sounds in all quadrants. Laboratory findings, except leukocytosis $\left(11,000 \mathrm{~mm}^{3}\right)$, were normal. $\mathrm{Ab}-$ dominal radiograph was obtained first in this patient with acute symptoms, which revealed air-fluid levels that suggested intestinal obstruction (Fig. 1a). In addition to these important findings, abdominal tenderness especially in the right lower quadrant and a palpable mass were present. The patient was operated with the diagnosis of plastron appendicitis. The abdomen was entered by McBurney incision. In the exploration, the appendix was seen to be normal and there was an ileocecal intussusception due to Meckel's diverticulum. The intussusception was reduced manually (Figs. 1b, c). Meckel's diverticulum was resected in the form of wedge resection. The postoperative period was uneventful and the patient was discharged on postoperative day 4.

Case 2- A 42-year-old male patient with no previous abdominal surgery, who experienced severe abdominal pain and vomiting in the course of one day, was admitted to the emergency service of our hospital. There was no significant medical history. His body temperature was $37.6^{\circ} \mathrm{C}$ and vital signs were stable. His abdomen was very tender and distended, and bowel sounds were hyperactive. There was no palpable mass. Laboratory findings showed a white blood cell count (WBC) of $9,600 \mathrm{~mm}^{3}$, hemoglobin $12.3 \mathrm{~g} / \mathrm{dl}$, and platelets 280,000 . All other studies, in- 

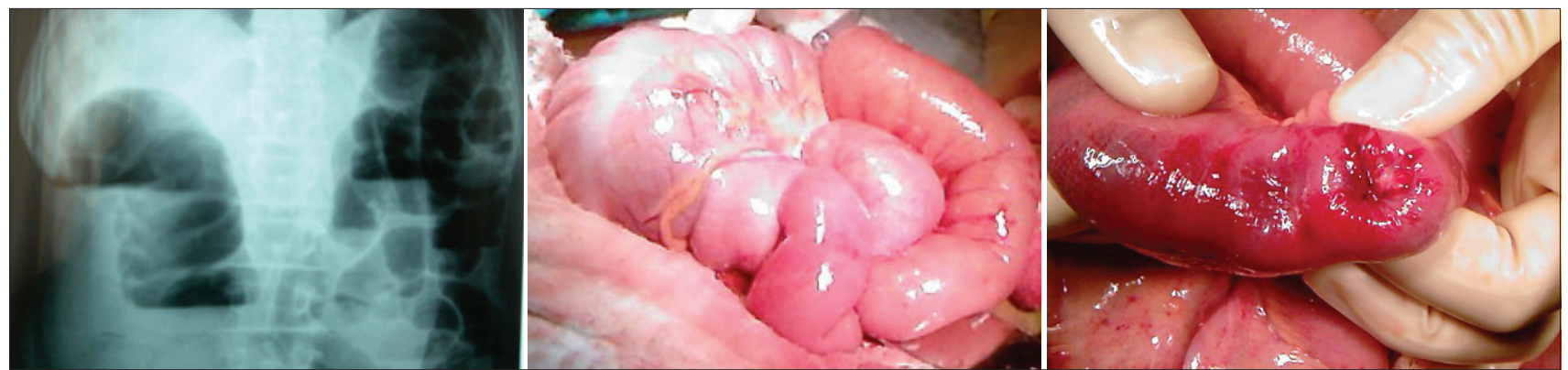

Fig. 1. (a) Abdominal radiograph revealed the presence of distended jejunal and ileal bowel loops. (b) Ileocecal intussusception. (c) Ileocecal intussusception due to Meckel's diverticulum.

(Color figures can be viewed in the online issue, which is available at www.tjtes.org).

cluding electrolytes and urinalysis, were within normal limits. There were air-fluid levels on the abdominal radiograph. Computed tomography (CT) showing marked dilatation of the small intestine suggested the obstruction was near the ileocecal valve (Fig. 2a). He was diagnosed with mechanical intestinal obstruction, and nasogastric decompression was performed. Emergency exploratory laparotomy was performed under general anesthesia. The distal part of the ileum was markedly dilated and formed a loop, clasped at its base by a loop-like structure located $70 \mathrm{~cm}$ proximal to the ileocecal valve (Fig. 2b). After separating the structure from the mesentery, it proved to be Meckel's diverticulum, the end of which was adhered to the corresponding dorsal mesentery. The ileal loop was released from the diverticulum. The necrotic segment and Meckel's diverticulum were resected and functional end-to-end anastomosis of the bowel was completed. The diverticulum was confirmed as Meckel's diverticulum by histological examination. The postoperative period was uneventful, and the patient was discharged on postoperative day 10 .

Case 3- A 19-year-old man with no previous abdominal surgery presented with a 24-hour history of abdominal pain, nausea and vomiting. There was no significant medical history. His body temperature was $36.5^{\circ} \mathrm{C}$ and the vital signs were stable. His abdomen was very tender and distended. Bowel sounds were hypoactive. The rectal exam showed an empty vault. No masses were palpable. WBC count was $9.0 \times 10^{3}$ $/ \mathrm{mm}^{3}$ with $94.5 \%$ neutrophils, hemoglobin was 9.0 $\mathrm{g} / \mathrm{dl}$ and hematocrit was $31.3 \%$; liver and pancreatic enzymes were not elevated. An abdominal radiograph showed air-fluid levels of the small intestine, suggesting a complete obstruction of the small intestine. Abdominal CT showed marked dilatation of the stomach and small intestine and suggested the obstruction was near the ileocecal valve. The patient was diagnosed as having intestinal obstruction. Emergent laparotomy showed a Meckel's diverticulum that had formed a band around a portion of the small bowel causing it to twist upon itself with subsequent necrosis. Resection of the Meckel's diverticulum with necrotic segment of the intestine and functional end-to-end anastomosis were performed. The diverticulum was confirmed as Meckel's diverticulum by histological examination. The patient recovered without any complications and was discharged on the fifth day of hospitalization.
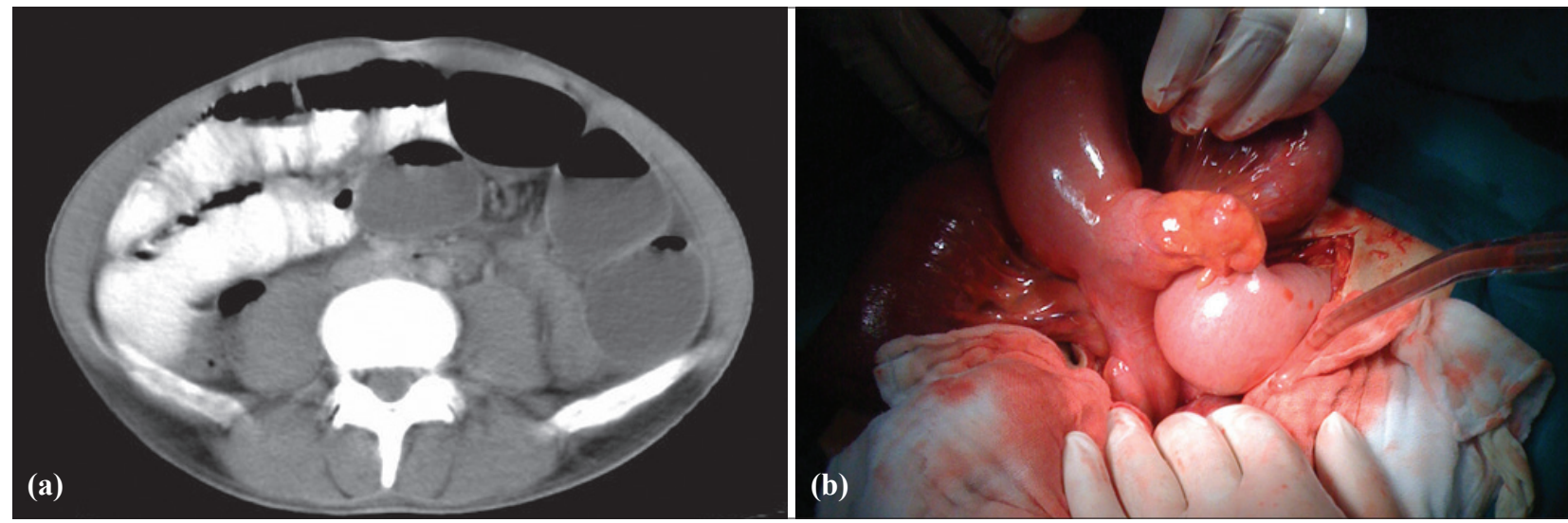

Fig. 2. (a) Computed tomography (CT) showing marked dilatation of the small intestine suggested the obstruction was near the end of the ileum. (b) Meckel's diverticulum and necrotic ileal segment. (The distal part of the ileum was markedly dilated and formed a loop, clasped at its base by a loop-like structure located $70 \mathrm{~cm}$ proximal to the end of the ileum.) (Color figures can be viewed in the online issue, which is available at www.tjtes.org). 


\section{DISCUSSION}

Meckel's diverticulum was first described by Fabricius Hildanus in 1598. The name derives from the German anatomist Johann Friedrich Meckel, who described the embryological and pathological features in $1809 .{ }^{[8]}$ Meckel's diverticulum is a common abnormality of the gastrointestinal tract, and is a remnant of the omphalomesenteric duct that is assumed to disappear at birth. The incidence of Meckel's diverticulum is about $1-3 \%$; most cases are asymptomatic and are found during laparotomy or autopsy ${ }^{\left[{ }^{[1]}\right.}$ Meckel's diverticulum is the most common end result of the spectrum of omphalomesenteric duct anomalies, which also include umbilico-ileal fistula, omphalomesenteric duct sinus, omphalomesenteric duct cyst, fibrous connection of the ileum to the umbilicus, and Meckel's diverticulum, with the latter being the most common (98\% of cases) of the omphalomesenteric duct anomalies. The diverticulum is usually found within $100 \mathrm{~cm}$ of the ileocecal valve on the antimesenteric border of the ileum. ${ }^{[1,9]}$ The complications of Meckel's diverticulum are hemorrhage, intestinal obstruction and diverticulitis. Intestinal obstruction is the second most common complication of Meckel's diverticulum. ${ }^{[2,10]}$ There are many mechanisms for small intestinal obstruction from a Meckel's diverticulum. It may produce obstruction by diverticular inversion causing luminal obstruction or leading to an intussusception, volvulus from persistent attachment to the umbilicus, adhesions, congenital meso-diverticular bands, diverticulitis, foreign body impaction, inclusion of the diverticulum into a hernia, neoplasm, Meckel's diverticulum lithiasis, or formation of a loop. ${ }^{[5,6]} \mathrm{A}$ band extending between the diverticulum and the base of the mesentery can also form a loop in which a part of the ileum may get stuck, causing obstruction. ${ }^{[7]}$ Other mechanisms involve rare causes of obstruction like tumors (lipomas, carcinoid tumors and others), impacted meconium in neonates causing inflammatory adhesions of Meckel's diverticulum to surrounding structures leading to volvulus, cecal volvulus around the band extending from Meckel's diverticulum to the umbilicus, gallstone ileus, and obstruction secondary to phytobezoar formation in the Meckel's diverticulum. ${ }^{[10]}$

Complications occur more frequently in males. Most patients who develop symptoms are younger than 10 years. While bleeding is the most common complication in children, intestinal obstruction seems to be the most common complication in the adult age group. ${ }^{[2,6]}$ The important aspect of our cases was that all patients were adults.

Abdominal radiograph may reveal dilated bowel loops and multiple air-fluid levels. Although of limited value, sonography has been used for the investigation of Meckel's diverticulum. High-resolution sonography usually shows a fluid-filled structure in the right lower quadrant having the appearance of a blind-ending, thick-walled loop of bowel. CT has 9094\% sensitivity and 96-100\% specificity for the diagnosis of small bowel obstruction and a $40-73 \%$ positive predictive value for predicting the cause of the obstruction. ${ }^{[11]}$ Therefore, it is difficult to use CT to accurately identify a Meckel's diverticulum as the cause of intestinal obstruction. ${ }^{[4]}$ Abdominal CT is used for complicated cases such as intussusceptions. CT can help to confirm the presence of intussusception and to distinguish between lead point and non-lead point intussusceptions.

Correct diagnosis of Meckel's diverticulum before an operation is often difficult because a complicated Meckel's diverticulum simulates many other abdominal pathologies. The patient typically presents with the features of small bowel obstruction like absolute constipation, spasmodic abdominal pain, vomiting (which may be bilious), and abdominal distention.

The optimal treatment of adult intussusception is not agreed on universally. All authors agree that laparotomy is mandatory, in view of the likelihood of identifying a pathologic lesion. Most authors recommend a segmental small bowel resection of the invaginated part as surgical treatment of the intussusception. ${ }^{[12]} \mathrm{In}$ case of intussusception due to Meckel's diverticulum, the surgical treatment choice should be resection of the small bowel including the Meckel's diverticulum. In the first case, the Meckel's diverticulum was resected together with a small segment of the ileum, as in the literature. The operation should always include resection of the diverticulum or a segment of the bowel affected by the pathology. ${ }^{[13]}$

In conclusion, intestinal obstruction is the most common complication of Meckel's diverticulum. ${ }^{[1,5]}$ A preoperative diagnosis was not possible in view of the non-specific nature of the clinical and radiological findings. Intestinal obstruction due to Meckel's diverticulum might cause ileal strangulation because of acute obstruction. The clinician should be aware of this possibility and try to reach the diagnosis more quickly to avoid unnecessary bowel resection.

\section{REFERENCES}

1. Turgeon DK, Barnett JL. Meckel's diverticulum. Am J Gastroenterol 1990;85:777-81.

2. Kaya O, Moran M, Özdemir F, Çetinkünar S. A rare cause of intestinal obstruction: Meckel's diverticulitis. Turk J Med Sci 2008;38:277-9.

3. Arnold JF, Pellicane JV. Meckel's diverticulum: a ten-year experience. Am Surg 1997;63:354-5.

4. Levy AD, Hobbs CM. From the archives of the AFIP. Meckel diverticulum: radiologic features with pathologic Correlation. Radiographics 2004;24:565-87.

5. Park JJ, Wolff BG, Tollefson MK, Walsh EE, Larson DR. 
Meckel diverticulum: the Mayo Clinic experience with 1476 patients (1950-2002). Ann Surg 2005;241:529-33.

6. Dumper J, Mackenzie S, Mitchell P, Sutherland F, Quan ML, Mew D. Complications of Meckel's diverticula in adults. Can J Surg 2006;49:353-7.

7. Tomikawa M, Taomoto J, Saku M, Takeshita M, Yoshida K, Sugimachi K. A loop formation of Meckel's diverticulum: a case with obstruction of the ileum. Ulus Travma Acil Cerrahi Derg 2003;9:134-6.

8. Raymond P. Adjunctive procedure in intestinal surgery. Mastery of Surgery. 5th ed. 2007. p. 1392-3.

9. Yahchouchy EK, Marano AF, Etienne JC, Fingerhut AL.
Meckel's diverticulum. J Am Coll Surg 2001;192:658-62.

10. Sharma RK, Jain VK. Emergency surgery for Meckel's diverticulum. World J Emerg Surg 2008;3:27.

11. Nipper ML, Jacobson LK. Expanded applications of CT. Helical scanning in five common acute conditions. Postgrad Med 2001;109:68-70, 73-7.

12. Van Hee R, Brewaeys P, Buyssens N. Ileal intussusception due to invagination of Meckel's diverticulum. Acta Chir Belg 1992;92:55-9.

13. D'Souza CR, Kilam S, Prokopishyn H. Axial volvulus of the small bowel caused by Meckel's diverticulum. Surgery 1993;114:984-7. 